R. F. Jessup, officiel of the Midland Bank, Ltd., for a survey of Roman barrows in Britain and northern Europe; M. Kaufman, senior lecturer in plastics technology, National College of Rubber Technology, for his studies on the history and development of the plastics industry; W. A. Sands, senior scientific officer, H.M. Overseas Civil Service (Research Branch), for a revision of the termite subfamily Nasutitermitina from the Ethiopian zoogeographical region; Dr. E. C. Southward, independent research worker, Marine Biological Association, Plymouth, for studies on the biology of Pogonophora.

\section{Fishery Research Training Grants}

THE Ministry of Agriculture, Fisheries and Food and the Department of Agriculture and Fisheries for Scotland are offering a number of one-year postgraduate training grants in fishery research tenable from October 1. These grants are intended to enable selected candidates to undergo a specified course of training to fit them for the investigation of problems in marine or freshwater science. Applications will be considered from candidates for permission to register for a higher degree in circumstances where this seems likely to be consistent with the requirements of the approved fishery research training programme. The number of training grants to be awarded during 1961 will probably not exceed three. Both men and women are eligible to apply. Candidates must be British subjects and graduates with honours in science of a university or possess equivalent qualifications. The value of the training grant will depend on the centre at which training is undertaken, and on whether the student is able to live at home, but will not normally be less than $£ 270$ nor exceed $£ 420$ per annum. For candidates with two years postgraduate experience, however, a grant of up to $£ 470$ per annum may be awarded. Further informa. tion can be obtained from the Secretary, Development Commission, 3 Dean's Yard, Westminster, London, S.W.1.

\section{The Association of Applied Biologists}

THE following honorary officers were elected for 1961-62 at the recent annual general meeting: President, Dr. P. W. Brian; Vice-President, Dr. M. A. Watson; President-Elect, Prof. H. G. H. Kearns; Treasurer, Dr. F. Raw; General Secretary, Dr. L. Broadbent; Programme Secretary, M. J. Way; Editor, R. W. Marsh; Assistant Editor, Dr. I. Thomas. New members of Council elected were: Dr. F. T. Last, F. G. H. Lupton, Dr. D. Rudd Jones and D. W. Wright.

\section{American Society for Engineering Education}

THE following have been elected officers of the American Society for Engineering Education: President, Dr. Robert W. Van Houten, president of the Newark College of Engineering and director of the Newark Technical School; Vice-Presidents, Dr. George A. Marston, dean of Engineering at the University of Massachusetts, and Dr. Curtis L. Wilson, Dean of the Missouri School of Mines and Metallurgy; Treasurer, Wendel W. Burton, of the Minnesota Mining and Manufacturing Co.

The International Society for Research on the Reticuloendothelial System

THE following have been elected officers and council members of the International Society for
Research on the Reticuloendothelial System: President, Dr. Albert S. Gordon (United States); VicePresident (Europe), Dr. Bernard N. Halpern (France); Vice-President (Western Hemisphere), Dr. Ignacio Gonzalez-Guzman (Mexico); Vice-President (Asia), Dr. Kaneyoshi Akazaki (Japan); Secretary-Treasurer, Dr. John H. Heller (United States); Council, Dr. Shigeyasu Amano (Japan), Dr. Baruj Benacerraf (United States), Dr. Charles A. Doan (United States), Dr. Thomas F. Dougherty (United States), Dr. Tede Eston (Brazil), Dr. John F. Loutit (United Kingdom), Dr. Alberto M. Marmont (Itrly), Dr. A. Ashley Miles (United Kingdom), Dr. John W. Rebuck (United States), Dr. Jorge Da Silva Horta (Portugal), Dr. Bo Thorell (Sweden), and Dr. Guy Voisin (France).

\section{The International Union of Crystallography}

THE International Union of Crystallography has announced three fortheoming symposia: a symposium on "Electron and Neutron Diffraction", to be held at Kyoto, Japan, during September 25-30 (further information can be obtained from Prof. S. Miyake, Science Council of Japan, Ueno Park, Tokyo); a symposium in commemoration of the fiftieth anniversary of the discovery by Prof. Max von Laue of the diffraction of X-rays by crystals, to be held at Munich during July 25-28, 1962 (further information can be obtained from Prof. F. Bopp, Institut für Theoretische Physik der Universität, Geschw. SchollPlatz 1, Munich 22); sixth general assembly and international congress of the Union, to be held in Rome during September 9-18, 1963 (further information can be obtained from Dr. W. H. Taylor, Crystallographic Laboratory, Cavendish Laboratory, Cambridge).

\section{Rutherford Jubilee International Conference}

A CONFERENCE is to be sponsored by the International Union of Pure and Applied Physics, the Royal Society, the Institute of Physics and the Physical Society, and the University of Manchester, to commemorate the discoveries of Rutherford at Manchester, and in particular the fiftieth anniversary of the Rutherford scattering law. The conference will be held at the Physics Department, University of Manchester, during September 4-8. The programme has been divided into nine sessions : September 4 (1) high-energy investigations of nuclei (morning), (2) collective motion in nuclei (afternoon); September 5 (3) the nuclear ground-state (morning), (4) Rutherford at Manchester (afternoon); September 7 (5 and 6) direct interactions (morning and afternoon); September 8 (7) weak interactions (morning), (8) open session (afternoon), (9) conference summary. Further information can be obtained from Dr. L. J. B. Goldfarb, Rutherford Jubilee International Conference, Physics Department, The University, Manchester, England.

\section{University News:}

Belfast

Dr. R. Common has been appointed to a lectureship in geography, and Mr. M. Cohen has been appointed to a lectureship in applied mathematics.

\section{Birmingham}

DR. W. F. VINEN, university demonstrator in physics, University of Cambridge, has been appointed to a vacant established chair of physics within the Department of Physics from October 1, 1961. The title of professor of taxonomic botany has been con- 